\title{
Aktualisasi Nilai Demokrasi dalam Perekrutan dan Penjaringan Perangkat Desa
}

\author{
Burhanudin Mukhamad Faturahman ${ }^{1}$ \\ burhanmfatur@gmail.com
}

\begin{abstract}
Abstrak
Perekrutan perangkat desa secara selektif dan transparan dinilai penting dalam kehidupan demokrasi untuk menunjang pelayanan yang lebih baik kepada masyarakat. Oleh karena itu, penelitian ini bertujuan mengetahui proses penjaringan dan penyaringan perangkat desa Tiremenggal, Kabupaten Gresik secara langsung. Penelitian dilakukan dengan metode partisipatif yaitu pelibatan secara langsung dalam proses perekrutan perangkat desa kemudian data dianalisis secara deskriptif kualitatif. Hasil penelitian memberikan bukti bahwa proses perekrutan perangkat desa secara terbuka dan melibatkan pengawasan masyarakat secara langsung mengurangi rasa curiga antar masyarakat di Desa Tiremenggal. Kepuasan oleh masyarakat Desa Tiremenggal ini disebabkan karena selama ini proses perekrutan perangkat desa cenderung tidak terbuka. Sehingga perekrutan perangkat desa secara terbuka dan melibatkan pengawasan masyarakat secara langsung merupakan unsur penting dalam menjaga kehidupan demokrasi.
\end{abstract}

Kata Kunci: Demokrasi, Desa, Nilai, Perangkat, Perekrutan

\begin{abstract}
Recruitment of Councilor selectively and transparently assessed importance in the life of a democracy to support better service to the community. Therefore, this research aims to know the process of Councilor recruitment Tiremenggal village Gresik Regency directly. Research done by the participatory method, namely the involvement of directly in the recruitment process of the Councilor then a data is analyzed the descriptive qualitative. Research results provide evidence that the recruitment process Councilor openly and involves surveillance of communities directly reducing suspicion between society in the village of Tiremenggal. Satisfaction by the villagers Tiremenggal this is because during the process of recruitment of Councilor tend not to open. So recruiting Councilor openly and engage the community in direct supervision is an important element in maintaining the life of democracy..
\end{abstract}

Keywords: Administration, Democracy, Village, Value, Recruitment

\section{Pendahuluan}

Pelaksanaan demokrasi tingkat lokal merupakan hal yang fundamental jika negara ingin menjalankan demokrasi menyeluruh mulai dari tingkat nasional hingga lingkup pemerintahan terkecil yaitu desa. Oleh karena itu, untuk memenuhi tuntutan demokrasi tersebut, Undang-Undang Nomor 6 Tahun 2014 Tentang Desa membuka kesempatan seluas-luasnya kepada pemerintah desa dibantu perangkat desa sebagai

\footnotetext{
${ }^{1}$ Korespondensi: Burhanudin Mukhamad Faturahman. Program Pascasarjana Ilmu Administrasi Universitas Brawijaya. Jalan M.T. Haryono No.163. Telp.(0341) 553737
} 
unsur penyelenggara pemerintahan di desa sebagaimana bunyi dari pasal 25 UU Desa tersebut. Unsur desa sebagai wilayah otonom diberi kewenangan secara khusus dalam mengatur, mengurus rumah tangganya sendiri termasuk dalam hal pengangkatan dan pemberhentian perangkat desa. Hal ini diatur dalam pasal 26 (2) UU Desa bahwa untuk melaksanakan tugas, kepala desa berwenang mengangkat dan memberhentikan perangkat desa sesuai kebutuhan sumber daya manusia di desa yang bersangkutan.

Proses perekrutan perangkat desa dinilai penting dalam upaya menunjang jalannya pemerintahan desa yang efektif, maka kepala desa perlu mengangkat perangkat desa yang berorientasi pada kinerja. Secara konsep, kinerja menurut Simanjuntak (2005:1) merupakan tingkatan pencapaian hasil atas pelaksanaan tugastugas tertentu. Dengan demikian, kinerja yang lebih intensif serta optimal diperlukan demi optimalisasi bidang tugas yang dibebankan kepadanya. Utami (2015) mengungkapkan bahwa terdapat pengaruh dalam perekrutan perangkat desa terhadap kinerja perangkat pemerintah daerah di Kecamatan Randudongkal Kabupaten Pemalang. Sementara itu, menurut Muhiubllah (2016), pengangkatan perangkat desa telah sesuai dengan implementasi perda Klaten Nomor 10 Tahun 2006 namun setiap desa melakukan improvisasi yang beragam tetapi dipastikan tidak melanggar hukum, transparan, profesional, adil dan merasa tidak ada pihak yang dirugikan. Dengan demikian, perundang-undangan tentang desa telah diimplementasikan dalam proses perekrutan perangkat desa sebagai wujud otonomi desa.

Desa Tiremenggal Kecamatan Dukun Kabupaten Gresik merupakan salah satu desa yang melakukan proses perekrutan dan penjaringan perangkat desa pada bulan Februari tahun 2018 melalui tes ujian tulis sebagaimana yang diatur dalam Perbup Gresik Nomor 8 Tahun 2014 Tentang Pedoman Teknis Pengangkatan Perangkat Desa. Proses seleksi dilakukan oleh tim Penjaringan dan Penyaringan Perangkat Desa (P3D) dengan melibatkan sumber daya desa setempat. Penelitian ini dimaksudkan untuk mengungkap sisi keterbukaan dalam proses ujian tes tulis serta proses penilaian skor akhir peserta ujian hingga ditetapkan peserta yang lolos tes ujian di mana keterbukaan atau transparansi ini merupakan salah satu nilai dari demokrasi dalam rangka perekrutan perangkat Desa Tiremenggal yang dapat dipertanggungjawabkan. 


\section{Tinjauan Pustaka}

\section{Teori Demokrasi}

Berdemokrasi bisa kita pahami sebagai konsep yang memiliki ruang lingkup cukup luas. Jika dilihat dari keadaan faktualnya, demokrasi di Indonesia masih berjalan sebagai proses di mana secara substansial keseimbangan berbagai unsur masyarakat baik partai, lembaga antar pemerintah, organisasi masyarakat menjadi tema yang menarik untuk dikaji. Sehingga apapun bentuknya, fenomena demokrasi di Indonesia baik di tingkat pusat hingga tingkat daerah sangat menarik untuk dibicarakan. Menurut Mas'oed (1999:6), demi kelestarian demokrasi diperlukan sebuah kesepakatan dari rakyat mengenai makna demokrasi itu sendiri dari segi mekanisme kerja demokrasi dan kegunaan demokrasi bagi kehidupan. Kekuatan demokrasi berasal dari kehendak rakyat sendiri bertujuan untuk mencapai kebaikan bersama sehingga persoalan demokrasi berkaitan dengan persoalan terakomodirnya atau keterwakilan kehendak rakyat itu sendiri.

Mengutip teori dari Rousseau (2007), demokrasi adalah tahapan yang harus dilewati bagi negara jika ingin sejahtera. Pernyataan ini merujuk bahwa demokrasi sebagai acuan bagi semua negara jika ketatanegaraan suatu negara ingin sempurna. Kemudian Rousseau menambahkan bahwa kesepurnaan bukanlah milik manusia begitu pun demokrasi. Demokrasi dimaknai bukan sebagai tujuan akhir namun lebih melihat kepada fakta tahapan yang ada atau sedang berlangsung. Demokrasi akan berjalan beriringan dengan berkembangnya zaman dan dipengaruhi oleh budaya sebuah negara. Sehingga jika demokrasi diterapkan secara kaku dan terlalu ideal, demokrasi yang nyata tidak akan terwujud.

Selanjutnya, esensi dari demokrasi sendiri berupa kompromi dalam penyelesaian sebuah masalah. Kelsen (2006) menyatakan esensi demokrasi terdapat pada adanya kompromi dalam menyatukan pendapat yang berbeda. Prinsipnya ada pada penyelesaian konflik melalui norma yang tidak seluruhnya sesuai dengan kepentingan dari salah satu pihak, dan juga tidak seluruhnya bertentangan dengan kepentingan lainnya. Kompromi tersebut cerminan cita-cita dalam penentuan kehendak sendiri secara sempurna dan terus menjadi pembahasan antara kepentingan mayoritas dan kepentingan minoritas agar terjadi kesepakatan bersama dan menjadi pegangan masyarakat dalam menjalani kegiatan sehari-hari. 
Arahan daripada sikap kompromi ini menunjukkan bahwa demokrasi juga dipengaruhi oleh budaya suatu masyarakat yang selalu mengutamakan kesepakatan bersama ketika terjadi permasalahan tidak saja diterapkan dalam kelembagaan formal dan non formal, akan tetapi juga sebagai solusi pemecahan masalah yang sifatnya horizontal di antara beragamnya kepentingan di masyarakat. Kompromi tersebut merupakan salah satu ciri yang dijadikan pegangan untuk memahami demokrasi. Kelsen dalam Thalhah (2009:418) memberikan prinsip dalam memahami demokrasi yakni: (1) adanya kehendak mayoritas dan minoritas, (2) kehendak mayoritas tidak bisa menjadi dominasi absolut (mutlak), (3) kompromi dikedepankan di antara kehendak mayoritas dengan kehendak minoritas dalam menyikapi sebuah permasalahan serta solusi, (4) tidak ada paksaan dalam beragama dan berkeyakinan, (5) terdapat kebebasan berbicara, kebebasan pers, dan pendapat untuk mengemukakan pendapat dijamin keberadaannya, baik melalui konstitusi ataupun melalui kesepakatan adat, dan (6) tidak diketemukannya benturan kepentingan antara kehendak mayoritas dan kehendak minoritas adalah ciri kompromi yang sehat.

\section{Keterbukaan dan Inklusivitas}

Pendefinisian konsep keterbukaan dan inklusivitas menurut Denhardt dan Denhardt (2007) merupakan dua nilai kunci dalam demokrasi yang dianut dari sebuah legitimasi pada pemerintahan yang demokratis. Keterbukaan yang demokratis dapat dipahami sebagai akses terhadap informasi dan transparansi proses. Dengan demikian, kemudahan masyarakat ataupun pihak-pihak lain untuk mengetahui berbagai kegiatan pemerintahan terkait kebijakan publik tanpa hambatan adalah elemen penting demokrasi.. Akses terhadap informasi menuju keterbukaan bermula dari sifat kerahasiaan dan yang lebih menarik lagi dikarenakan saat ini penggunaan teknologi membuat akses terhadap informasi lebih mudah dan harapan penyebarannya lebih luas kepada masyarakat.

Selanjutnya, setelah keterbukaan terhadap informasi, aspek penting keterbukaan lainnya adalah transparansi dalam pengambilan keputusan pemerintah yang sepenuhnya terbuka bagi pengawasan publik artinya pemerintah harus membuka ruang seluas-luasnya bagi publik untuk bersama-sama mengawasi keputusan pemerintah. Dengan begitu, masyarakat menjadi mengerti dan memahami bagian 
penting dalam proses kebijakan publik. Hal ini dikarenakan setiap keputusan yang dibuat ditujukan untuk masyarakat adalah sebagai solusi dari berbagai masalah yang muncul di masyarakat itu sendiri. Istilah transparansi dalam administrasi publik sering dikaitkan dengan konsep akuntabilitas pemerintah yaitu legitimasi pemerintahan yang demokratis harus bertanggung jawab kepada rakyat melalui proses transparansi dari keputusan yang dibuat (Florini, 2004).

Inklusivitas merujuk pada representasi dan partisipasi seperti yang diungkapkan Rossmann dan Shahnan (2012). Representatif menerangkan kepentingan umum dicapai melalui sifat inklusif perwakilan dalam administrasi publik yang secara luas mencerminkan kepentingan, pendapat, kebutuhan, keinginan dan nilai-nilai masyarakat. Partisipasi masyarakat merupakan definisi kedua dari inklusivitas di mana pemerintahan demokratis didasarkan pada efektivitas partisipasi warga negara bertujuan meningkatkan peran partisipasi masyarakat secara aktif di dalam program pemerintah. Ukuran dari partisipasi masyarakat adalah mekanisme partisipasi dan tingkat kualitas keterlibatan masyarakat dalam partisipasi publik.

Nilai demokrasi penting lainnya yaitu responsivitas. Responsivitas ini dapat ditingkatkan (lebih responsif) dengan memperhatikan pluralisme, kreativitas dan keadilan dalam pelayanan publik. Pluralisme identik dengan kemajemukan apabila dihubungkan dengan pelayanan oleh pemerintah maka tuntutan pelayanan yang beragam harus dilakukan karena jika memberikan pelayanan yang sama kepada seluruh masyarakat yang majemuk maka pelayanan oleh pemerintah cenderung kurang responsif. Kreativitas membentuk cara terbaik dalam menyelesaikan masalah beserta proses pembelajarannya yaitu menggunakan rasionalitas dan hati nurani. (Dwiyanto, 2010).

Selain itu, nilai keadilan merupakan kewajaran dalam hal distribusi biaya dam manfaat. Artinya keadilan lebih menekankan proporsionalitas dalam memberikan pelayanan kepada masyarakat. Nilai keadilan sekaligus menjadi tantangan dalam pemerintahan demokrasi dengan menyadari bahwa rasionalitas dari keberadaan pemerintah adalah mewujudkan keadilan dalam pemenuhan kebutuhan masyarakat.

\section{Lembaga Demokrasi di Desa}


Menjadi sebuah keharusan kelembagaan desa sebagai lembaga yang menjamin demokrasi seperti yang telah di atur UU Desa yakni yakni, (1) Kepala Desa dibantu oleh perangkat Desa, dan (2) Badan Permusyawaratan Desa atau BPD. Selain itu desa sebagai arena politik, ekonomi, sosial dan budaya juga diwajibkan dalam mengembangkan, menjalankan, dan mengawasi pelaksanaan demokrasi desa.

Tabel 1. Pemangku Kewajiban Demokrasi

\begin{tabular}{l|l} 
Kepala desa & $\begin{array}{l}\text { Melaksanakan kehidupan } \\
\text { demokrasi dan berkeadilan } \\
\text { gender }\end{array}$ \\
\cline { 2 - 2 } & $\begin{array}{l}\text { Kewajiban di atas ditegaskan } \\
\text { juga sebagai komitmen } \\
\text { jabatan Kepala Desa dalam } \\
\text { sumpah jabatan }\end{array}$ \\
\hline Badan Permusyawaratan & $\begin{array}{l}\text { Melaksanakan kehidupan } \\
\text { demokrasi yang berkeadilan } \\
\text { Dender dalam penyelenggaraan } \\
\text { Pemerintahan Desa }\end{array}$ \\
\cline { 2 - 2 } & $\begin{array}{l}\text { Kewajiban di atas ditegaskan } \\
\text { juga sebagai komitmen } \\
\text { jabatan Kepala Desa dalam } \\
\text { sumpah jabatan }\end{array}$ \\
\hline Desa & $\begin{array}{l}\text { Mengembangkan kehidupan } \\
\text { demokrasi }\end{array}$ \\
\hline
\end{tabular}

Sumber: UU No.6 Tahun 2014

\section{Rekrutmen Perangkat Desa}

Proses rekrutmen merupakan cara memanajemen karyawan atau pegawai dalam sebuah organisasi agar dapat menjalankan sebuah organisasi secara efektif. Secara teoritis, unsur manajemen meliputi man, money, methods, materials, machine, market. Unsur manusia sebagai penggerak utama organisasi/lembaga yang harus melalui proses seleksi terlebih dahulu sehingga dikenal manajemen kepegawaian. Dalam pembahasan ini, penulis lebih menekankan unsur manusia sebagai faktor penentu dalam sebuah proses seleksi berdasarkan indikator yang telah ditentukan.

Karyawan atau pegawai adalah aset utama atau pelaku utama yang menjadi perencana, pembuat keputusan dan pelaku aktif dari organisasi. Mereka memiliki pikiran, keinginan, perasaan, status, latar belakang pendidikan, usia, dan jenis kelamin yang heterogen. Mereka bukanlah mesin, uang, dan material yang sifatnya pasif dan 
dapat diatur sepenuhnya dalam mendukung tercapainya tujuan. Kemampuan dan keterampilan pegawai belum menjamin produktivitas kerja yang baik jika moral kerja dan kedisiplinannya rendah. Mereka dapat dikatakan bermanfaat mendukung terwujudnya tujuan jika mereka berkeinginan tinggi untuk berprestasi.

Kualitas dan kuantitas pegawai harus sesuai dengan kebutuhan agar menunjang tercapainya tujuan secara efektif dan efisien. Penempatan tenaga kerja juga harus tepat sesuai dengan kapasitasnya. Dengan demikian, gairah kerja dan kedisiplinannya akan lebih baik serta efektif menunjang terwujudnya tujuan organisasi. Oleh karena itu, pengadaan karyawan atau pegawai harus didasarkan pada prinsip apa baru siapa. Apa artinya menetapkan terlebih dahulu pekerjaan-pekerjaannya berdasarkan uraian pekerjaan (job description). Siapa artinya mencari pegawai yang tepat untuk menduduki jabatan tersebut berdasarkan spesifikasi pekerjaan (job specification).

Pengadaan pegawai berdasarkan siapa kemudian apa, menimbulkan ketidakcocokan atau mismanajemen dalam penempatan. Penempatan pegawai yang jauh di luar kemampuannya mengakibatkan moral kerja, semangat kerja dan kedisiplinan menjadi rendah. Adapun proses rekrutmen pegawai (Utami, 2015:30-31), yaitu (1) Peramalan kebutuhan tenaga kerja; (2) Penarikan (recruitment); (3) Seleksi (selection); dan (4) Penempatan, orientasi, dan induksi karyawan atau pegawai.

Perekrutan pegawai hendaknya dilakukan dengan baik dan benar sehingga pegawai yang diterima sesuai dengan kebutuhan pekerjaan yang akan dilakukan. Dalam penelitian ini, penulis menjelaskan tentang proses rekrutmen perangkat desa bahwa keterlibatan partisipasi masyarakat luas sangatlah penting terhadap dalam proses rekrutmen perangkat desa sebagai wujud dari kehidupan demokrasi.

Rekrutmen menurut Sukamti (1989:133) adalah serentetan kegiatan oleh organisasi untuk menarik calon pegawai yang memiliki kemampuan dan sikap yang dibutuhkan dalam mencapai tujuan. Selanjutnya, istilah rekrut berarti serentetan kegiatan atau rangkaian kegiatan dan proses sah untuk mendapatkan orang-orang yang tepat dalam jumlah yang cukup. Jadi rekrutmen adalah sebuah proses dalam mendapatkan sejumlah orang dengan kriteria tertentu untuk menghasilkan kualitas tertentu pula di bidang kemampuannya untuk bekerja di organisasi atau lembaga yang menyediakan fasilitas perekrutan. 
Proses rekrutmen perangkat Desa Tiremenggal sendiri telah diatur dalam Peraturan Bupati Gresik Nomor 8 Tahun 2014 Tentang Pedoman Teknis Pengangkatan Perangkat Desa pasal 9 ayat 1 yaitu masyarakat yang dapat diangkat menjadi Perangkat Desa adalah penduduk desa setempat Warga Negara Republik Indonesia yang (1) Bertakwa kepada Tuhan Yang Maha Esa; (b) Setia kepada Pancasila sebagai Dasar Negara, Undang-Undang Dasar Negara Republik Indonesia Tahun 1945, Negara Kesatuan Republik Indonesia, dan Pemerintah; (c) Berusia paling rendah 20 (dua puluh) tahun dan paling tinggi 60 (enam puluh) tahun, dibuktikan dengan Akta kelahiran atau alat keterangan pembuktian kelahiran yang lain, terhitung pada saat penutupan pendaftaran; (d) Berpendidikan paling rendah Sekolah Lanjutan Tingkat Pertama dan/atau sederajat, yang dibuktikan dengan ijazah/Surat Tanda Tamat Belajar (STTB) pendidikan formal dari tingkat dasar sampai dengan ijazah/STTB terakhir yang dilegalisir oleh pejabat yang berwenang; (f) Bersedia bertempat tinggal tetap di Desa setempat; (g) Bertempat tinggal di wilayah kerjanya, bagi Calon Kepala Dusun; (h) Sehat jasmani dan rohani, dibuktikan dengan surat keterangan dokter dari Rumah Sakit Pemerintah atau Puskesmas setempat; (i) Berkelakuan baik, dibuktikan dengan surat keterangan catatan kepolisian atau keterangan lain dari Kepolisian Sektor setempat; (j) Tidak pernah dihukum karena melakukan tindak pidana kejahatan yang ancaman pidananya minimal 5 tahun penjara berdasarkan keputusan pengadilan yang telah memperoleh kekuatan hukum tetap yang dibuktikan dengan surat pernyataan; $(\mathrm{k})$ Terdaftar sebagai penduduk desa setempat paling sedikit 2 (dua) tahun terakhir berturut-turut, dibuktikan dengan Kartu tanda Penduduk (KTP) atau Kartu Keluarga $(\mathrm{KK})$, kecuali bagi putra desa.

Dengan dilaksanakannya proses rekrutmen perangkat Desa Tiremenggal maka dibentuk tim Penjaringan dan Penyaringan Perangkat Desa (P3D) dengan tugas sebagaimana pasal 12 Peraturan Daerah Kabupaten Gresik Nomor 2 Tahun 2016 yakni menyusun jadwal kegiatan; mengelola anggaran secara efisien, efektif, transparan dan akuntabel; serta menyusun tata tertib sesuai dengan ketentuan peraturan perundangundangan. Kemudian, melaksanakan sosialisasi lowongan perangkat desa kepada masyarakat; melaksanakan penjaringan/pendaftaran bakal calon perangkat desa; melaksanakan penyaringan/ujian seleksi calon perangkat desa; dan menyiapkan tempat ujian calon perangkat desa. Selanjutnya, melaksanakan penilaian hasil ujian calon 
perangkat desa; melaksanakan tertib administrasi pelaksanaan penjaringan dan penyaringan perangkat desa; menyampaikan laporan kepada kepala desa untuk setiap tahapan pelaksanaan penjaringan dan penyaringan perangkat desa disertai berita acara dan menyampaikan informasi kepada masyarakat; memperlakukan bakal calon perangkat desa secara adil dan setara; melaksanakan tahapan pelaksanaan penjaringan dan penyaringan perangkat desa tepat waktu; dan mempertanggungjawabkan penggunaan anggaran kepada Kepala Desa.

\section{Metode Penelitian}

Pengumpulan data dalam penelitian ini melalui metode observasi, dokumentasi, dan wawancara dengan tim P3D dan posisi peneliti sebagai tim penguji dan pengawas ujian tes tertulis (partisipatif) Desa Tiremenggal selama satu hari. Observasi adalah metode ilmiah sebagai pengamatan dan pencatatan dengan sistematika fenomena-fenomena yang diamati. Dalam penelitian ini mengamati tes tertulis rekrutmen perangkat desa terhadap kinerja perangkat pemerintah Desa Tiremenggal di Kecamatan Dukun Kabupaten Gresik.

Adapun metode dokumentasi adalah mencari data mengenai sesuatu berupa catatan, transkrip, buku, surat kabar, majalah, prasasti, notulen rapat, agenda dan sebagainya dilakukan secara sistematis dan digunakan untuk memperoleh data yang berkaitan dengan objek penelitian. Sementara wawancara adalah teknik pengumpulan data apabila peneliti ingin melakukan studi pendahuluan untuk menemukan permasalahan yang harus diteliti, dan juga peneliti ingin mengetahui halhal dari respondennya sedikit/kecil. Wawancara dilakukan dengan teknik purposive interview dilakukan melalui tatap muka (face to face).

Selain itu, untuk data juga dikumpulkan melalui studi kepustakaan untuk mendukung data-data lapangan yang ada. Studi kepustakaan adalah pengumpulan data dengan mempelajari buku-buku rekrutmen, kinerja yang berhubungan dengan pokok bahasan dan permasalahan guna menganalisa dari objek penelitian. Selain itu, metode penelitian pendekatan kualitatif digunakan dalam melihat kompleksitas fenomena, meneliti kata-kata, laporan dari pandangan responden dan melakukan studi pada situasi yang dialami. Hasil analisis secara kualitatif kemudian diuraikan secara deskriptif 
berupa sajian kata-kata melalui urutan penyajian kondisi lapangan yang dilanjutkan dengan penarikan kesimpulan untuk memperoleh hasil akhir penelitian.

\section{Hasil dan Pembahasan}

\section{Nilai Demokrasi dalam Perekrutan Perangkat Desa}

Demokrasi setidaknya bisa dipahami melalui dua cara yaitu normatif dan empiris. Gaffar (2004:3-10) menyebutkan demokrasi secara normatif bersangkutan dengan sesuatu yang dianggap ideal hendak dilakukan oleh sebuah negara, semisal arti secara harfiah lewat ungkapan "pemerintahan dari rakyat, oleh rakyat, dan untuk rakyat". Untuk pemaknaan secara empiris, demokrasi terwujud dalam kehidupan praktis dalam menjalankan nilai-nilai ideal demokrasi itu sendiri. Penelitian ini menempatkan pemahaman demokrasi dari sudut pandang kedua sehingga nilai dan pengalaman sosial budaya di dalam proses Penjaringan dan Penyaringan Perangkat Desa (P3D) Tiremenggal Kecamatan Dukun Kabupaten Gresik membentuk pola ciri tingkah laku budaya demokrasi masyarakat dapat diungkapkan.

Nilai-nilai demokrasi dalam kehidupan budaya tidak terlepas dari kedudukan yang dilematis antara otonomi di satu pihak dan kontrol di pihak yang lain (Pelly, 1993:209). Pemerintah Desa Tiremenggal memiliki wewenang dalam proses perekrutan Perangkat Desa mengacu pada Peraturan Bupati Gresik Nomor 8 Tahun 2014 Tentang Pedoman Teknis Pengangkatan Perangkat Desa. Namun, di sisi lain masyarakat berhak mengetahui proses seleksi secara transparan dan dapat dipertanggungjawabkan. Sebagaimana wawancara yang dilakukan dengan panitia P3D desa setempat bahwa masyarakat Desa Tiremenggal sangat kritis terhadap proses perekrutan perangkat desa dikarenakan selalu terjadi konflik saat proses perekrutan. Hal ini dikarenakan masyarakat tidak lagi percaya kepada pemerintah desa yang tidak transparan. Sehingga dalam pelaksanaan tes P3D bulan Februari 2018 dilakukan secara terbuka dengan seluas-luasnya melibatkan pengawasan dari masyarakat secara langsung.

Peserta ujian tes tulis P3D berjumlah 5 orang dengan rincian formasi yang dilamar yaitu sekretaris desa sebanyak 3 orang dan kasi pelayanan sebanyak 2 orang. Peserta melakukan seleksi secara tertulis yang berlokasi di Balai Desa Tiremenggal dengan jumlah soal sebanyak 100 butir soal dengan durasi waktu selama 120 menit. 
Pembuatan soal ujian tertulis tersebut dibuat oleh Perguruan Tinggi setempat yang bekerja sama dengan panitia P3D Desa Tiremenggal. Pos keamanan juga dipercayakan pada Polsek Dukun sehingga dalam proses perekrutan tersebut pihak yang terlibat meliputi masyarakat Desa Tiremenggal, Tim P3D Desa Tiremenggal, Perguruan tinggi selaku pengawas dan penguji sekaligus pembuat soal ujian, dan Kepolisian untuk menjaga keamanan selama berlangsungnya ujian tulis.

Setelah ujian tertulis berjalan dengan kondusif maka dilakukan evaluasi penilaian dengan atas penilaian skor minimal untuk lolos seleksi yaitu 60. Berdasarkan hasil evaluasi maka peringkat skor tertinggi dari formasi sekretaris desa yaitu 78 sedangkan untuk formasi kasi pelayanan skor tertinggi yaitu 85. Saat proses evaluasi nilai dari peserta ujian, nilai demokrasi secara empiris dapat diungkap berupa pengawasan secara seksama disertai kompromi dalam mengatasi permasalahan.

\section{Gambar 1. Proses Penilaian Ujian Tertulis}

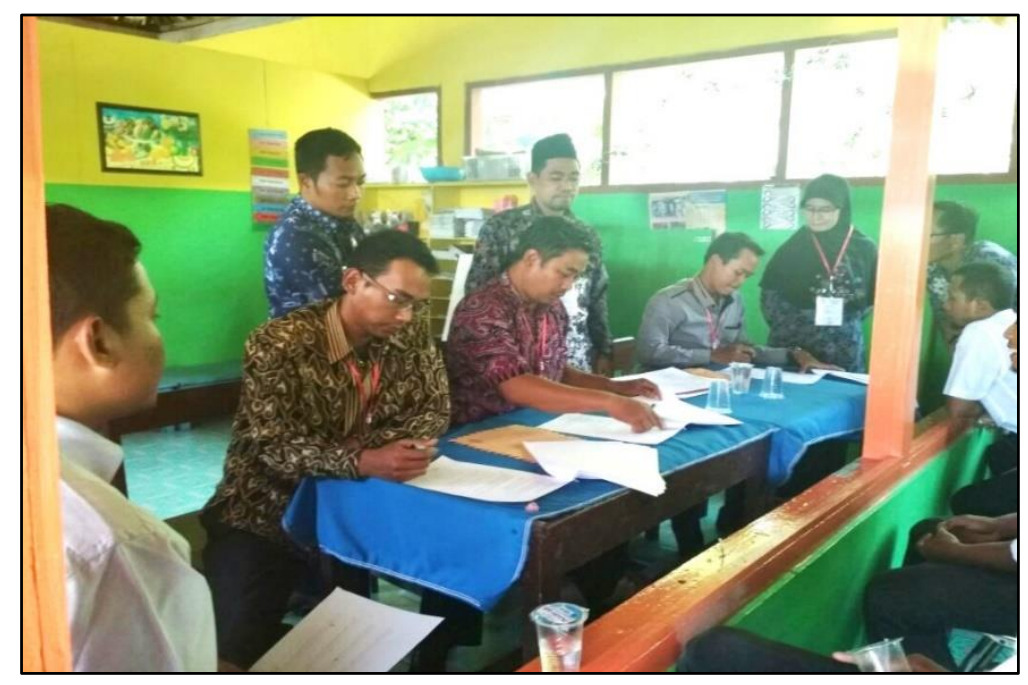

Sumber: dokumentasi penulis

Adapun permasalahan terjadi dikarenakan kesalahan teknis pengetikan dan kunci jawaban. Kesalahan teknis soal ujian dan kunci jawaban disepakati secara bersama oleh masing-masing pihak sehingga tidak ada ketegangan atau konflik dalam evaluasi ujian. Terlebih lagi semua merasakan kepuasan dikarenakan merasakan pengawasan secara langsung baik saat ujian tertulis dan evaluasi penilaian sehingga rasa curiga yang selama ini berkembang di Desa Tiremenggal saat proses perekrutan berbalik menjadi rasa percaya terhadap pihak penyelenggara. Selanjutnya peserta yang 
lolos ujian tulis diproses lebih lanjut sesuai Peraturan Bupati Gresik Nomor 8 Tahun 2014 Tentang Pedoman Teknis Pengangkatan Perangkat Desa.

\section{Manifestasi Nilai Demokrasi di Desa Tiremenggal}

Nilai dalam demokrasi memiliki arti penting bagi berjalannya kehidupan demokrasi dan desentralisasi yang sedang dikembangkan. Pola pergeseran sentralistik menjadi desentralistik merupakan wujud daripada kemauan menuju demokrasi yang lebih baik. Penelitian partisipatif yang dilakukan saat kegiatan P3D Desa Tiremenggal memberikan gambaran nyata terhadap nilai-nilai demokrasi yang terus berkembang dan mempengaruhi masyarakat Desa Tiremenggal sebagai kekuatan dan kemandirian demokrasi di desa di antaranya sebagai berikut:

Pertama, sistem perekrutan perangkat desa mengacu pada Peraturan Bupati Gresik Nomor 8 Tahun 2014 dijalankan dengan prinsip keterbukaan secara penuh. Jika pelaksanaan dalam setiap penyelenggaraan pemerintahan mengacu pada hukum normatif maka kehidupan demokrasi dari aspek hukum dijadikan sebuah solusi atas pertentangan di masyarakat sehingga masyarakat memiliki pedoman yang sistematis untuk ikut berpartisipasi dalam penyelenggaraan pemerintahan. Dengan dirujuknya aturan hukum tertentu dalam menjalankan kegiatan maka berbagai pihak menjadi mengerti dan paham tentang mekanisme kegiatan tertentu sehingga membentuk sikap tertentu pula jika terjadi kesalahan dalam pelaksanaannya.

Pemahaman makna hukum dirasa penting bagi pemerintahan tingkat desa untuk memberikan kesadaran hukum bagi masyarakat desa pada khususnya. Aristoteles menyebutkan esensi hukum dijadikan standar tunggal dan sama bersifat umum yang dinamakan keadilan korektif. Esensi ini adalah bagian dari konsekuensi dari tindakan yang dilakukan orang dalam hubungannya di masyarakat. Perbup merupakan standar hukum tunggal dalam perekrutan perangkat desa sehingga mekanisme menjadi dapat dipahami oleh masyarakat yang terlibat langsung untuk mengawasi proses perekrutan perangkat desa. Sedangkan keadilan distributif merupakan esensi hukum menyangkut soal pembagian barang-barang dan kehormatan pada masing-masing orang sesuai tempatnya. Keadilan yang sifatnya distributif ini tercermin pada kedudukan bagi peserta yang mengikuti selesai berasal dari desa 
setempat dan tidak dibedakan menurut jenis atau golongan tertentu dan mendapat kesempatan yang sama pula untuk mengikuti proses seleksi.

Kedua, masyarakat merasa perlu dalam mengawasi perekrutan perangkat desa karena stigma yang berkembang selama ini bahwa selalu terdapat rasa curiga terhadap kegiatan yang sama. Jika dalam teori demokrasi, kompromi merupakan salah satu cara dalam menyelesaikan masalah dalam kehidupan demokrasi juga memiliki sisi lainnya jika kompromi tersebut merupakan kompromi elit yang berkepentingan dalam menyusun rencana. Kompromi yang tertutup menimbulkan efek saling curiga di masyarakat. Higley dan Burton (1989:20) menambahkan bahwa perundingan (negosiasi) berkaitan tentang penciptaan rezim yang stabil karena adanya konsensus rezim tersebut. Untuk menghindari negosiasi yang sifatnya negatif maka pihak yang memiliki wewenang dalam kegiatan P3D Desa Tiremenggal membatasi sikap dan perilaku kepada aktor lain yaitu tim penguji dan pengawas ujian (perguruan tinggi sebagai pembuat naskah soal ujian) untuk meniadakan unsur kecurigaan di masyarakat saat pelaksanaan ujian. Inilah proses transisi dalam membentuk kepercayaan dapat dibangun dengan menunjukkan sikap dan perilaku yang mendukung proses transisi tersebut.

Ketiga, kesepakatan terbuka dan dapat diterima oleh semua pihak menjadi solusi ketika terjadi kesalahan teknis naskah ujian. Nilai-nilai demokrasi yang berkembang dalam kehidupan masyarakat Desa Tiremenggal mewariskan pikiran positif di mana perlu penguatan dalam kehidupan demokrasi. Kesalahan tidak dimaknai sebagai kegagalan akan tetapi dimaknai sebagai sikap saling memberi dan menerima pendapat sebagai evaluasi yang lebih baik serta memandang setiap makhluk hakikatnya sama dan memiliki kelebihan dan kelemahan sehingga terdapat kesetaraan dan penghargaan bagi hak setiap orang.

Masyarakat Desa Tiremenggal menganggap kegiatan P3D memiliki kedudukan penting sehingga diperlukan proses rekrutmen sebaik mungkin agar sistem pemerintahan di desa berjalan sesuai aturan yang berlaku. Kesaksian proses evaluasi nilai hasil ujian oleh masyarakat sendiri membentuk akuntabilitas tersendiri yaitu pengawasan dan keseimbangan antara pemerintah desa, tim P3D Desa Tiremenggal, mitra perguruan tinggi dan masyarakat Desa Tiremenggal. Hal tersebut dikarenakan 
perangkat desa merupakan "ujung tombak" dari pemerintahan daerah memiliki hubungan langsung dengan masyarakat dalam memberikan pelayanan.

Telah diuraikan sebelumnya bahwa kesepakatan merupakan wujud dari demokrasi desa sehingga menjadi basis sosio-budaya yang berarti demokrasi harus seiring dengan keterikatan atau loyalitas pada komunitas masyarakat desa setempat. Meletakkan kepentingan masyarakat sebagai prinsip demokrasi desa turut menjaga prinsip keterwakilan aspirasi masyarakat melalui: Musyawarah. Musyawarah merupakan pembahasan atas permasalahan tertentu dengan mengutamakan tukar pendapat serta argumentasi melibatkan seluruh elemen masyarakat. Musyawarah berbeda dengan pengambilan keputusan yang mengedepankan pemungutan suara. Prinsip musyawarah mengedepankan tukar pendapat, pandangan dan argumentasi sampai mencapai mufakat.

Musyawarah sebagai prinsip demokrasi desa adalah bagian dari rekognisi kearifan lokal yang dimiliki desa. Panitia Rekrutmen Perangkat Desa Tiremenggal dalam menyelesaikan masalah berupa kesalahan teknis pengetikan soal mencerminkan sikap sepakat mufakat yaitu bersikap saling menerima dan memberikan jalan keluar atau solusi secara damai dan santun, di mana demokrasi modern sering disebut demokrasi deliberatif. Demokrasi deliberatif mengedepankan akal dan pikiran jernih. Kesalahan teknis soal bukan sebagai masalah serius namun dianggap sebagai kesalahan yang wajar sebagai manusia biasa. Kemampuan untuk mencapai mufakat ini diperoleh dari pengalaman yang pernah dialami oleh setiap orang. Oleh karena itu, antara panitia dan peserta ujian sama-sama menerima kesalahan yang bersifat manusiawi. Terciptanya saling pengertian dan pemahaman merupakan syarat tercapainya mufakat dalam sebuah musyawarah.

Pengambilan keputusan dengan melibatkan masyarakat sangat nampak pada seleksi Perangkat Desa Tiremenggal. Partisipasi dalam kegiatan tersebut berupa pengawasan secara langsung evaluasi nilai akhir tes tertulis. Dengan melibatkan secara langsung partisipasi masyarakat dapat menjamin hak demokratik warga desa sebagai pemegang kekuasaan, artinya dengan terlibat secara langsung dalam pengawasan warga desa telah memiliki posisi penting dalam setiap pengambilan keputusan tingkat desa.

Sukarela dalam demokrasi memiliki keterkaitan dengan partisipasi dikarenakan kesadaran pribadi dari warga mampu mengoptimalkan pertimbangan akal 
sehat dalam memutuskan atas sesuatu hal. Makna sukarela selanjutnya yakni bebas dari ancaman atau intimidasi dalam menentukan sikap termasuk ancaman kekerasan dan politik uang. Sikap sukarela warga Desa Tiremenggal dapat dilihat dengan menghadiri setiap proses seleksi dari tahap awal hingga tahap akhir (evaluasi nilai). Kesukarelaan tersebut dipicu oleh isu kolusi yang sedang berkembang setiap kali kegiatan perekrutan perangkat desa dilaksanakan. Sebenarnya, sikap sukarela untuk ikut terlibat dalam setiap keputusan dapat dimunculkan dengan rasa keingintahuan secara mendalam terhadap persoalan yang kerap terjadi.

Terakhir, tansparansi. Proses politik Desa Tiremenggal dalam konteks Perekrutan Perangkat Desa adalah kegiatan yang berlangsung demi kepentingan masyarakat Desa Tiremenggal sendiri. Oleh sebab itu, warga desa harus mengetahui apa yang tengah terjadi/ berlangsung dalam proses politik. Prinsip transparan berarti tidak ada yang disembunyikan dari masyarakat desa serta kemudahan akses terhadap informasi. Sejauh ini proses politik dalam Perekrutan Perangkat Desa Tiremenggal berjalan dengan transparan dengan tidak menyembunyikan keputusan serta kemudahan informasi terkait peserta yang lolos seleksi ujian tertulis. Oleh karena itu, transparansi sangat diperlukan jika demokrasi di Desa Tiremenggal terus terjaga harmonis.

\section{Kesimpulan}

Kegiatan P3D Tiremenggal Kecamatan Dukun Kabupaten Gresik berjalan sesuai Peraturan Bupati Gresik Nomor 8 Tahun 2014 Tentang Pedoman Teknis Pengangkatan Perangkat Desa. Adapun pelaksanaan perekrutan melalui ujian tes tertulis secara terbuka sehingga kegiatan perekrutan dari awal hingga evaluasi penilaian akhir dapat diketahui oleh masyarakat Desa Tiremenggal. Hal ini dilakukan untuk mengurangi unsur kecurigaan yang selama ini dirasakan oleh masyarakat Desa Tiremenggal saat perekrutan perangkat desa.

Perekrutan yang selektif dan terbuka merupakan syarat bahwa kehidupan demokrasi dalam penyelenggaraan pemerintahan di tingkat desa mutlak diperlukan untuk menjaga keharmonisan sosial. Keharmonisan sosial merupakan cerminan dari nilai demokrasi yang berlandaskan kesesuaian hukum, kesadaran kolektif masyarakat serta menjunjung tinggi hak perseorangan maupun kelompok atas tugas dan tanggung 
jawab. Perilaku demokratis berdasarkan kompromi Desa Tiremenggal dapat dijadikan contoh untuk perekrutan pegawai di berbagai sektor pemerintahan baik pusat, daerah dan desa maupun legislatif. Kondisi tersebut dikarenakan semangat pengawasan secara kolektif dari masyarakat sangat nyata dan saling memiliki rasa toleransi terhadap kesalahan dalam rangka menjaga kelancaran proses perekrutan berdasarkan kesepakatan atau kompromi yang terbuka dan dapat dipertanggungjawabkan.

\section{Daftar Rujukan}

\section{Buku}

Denhardt, J., V. \& Denhardt, R., B. (2007). The New Publik Service: Serving, Not Steering. Armonk, NY: M. E. Sharpe.

Dwiyanto, A. (2010). Manajemen Pelayanan Publik: Peduli, Inklusif, dan Kolaboratif. Yogyakarta: Gadjah Mada University Press.

Gaffar, A. (2004). Politik Indonesia: Transisi Menuju Demokrasi. Yogyakarta: Pustaka Pelajar.

Kelsen, H. (2006). Teori Umum Tentang Hukum dan Negara, Cetakan pertama, Bandung: Nusamedia.

Pelly, U. (1996). Demokrasi Dalam Kehidupan Budaya dalam Membangun Martabat Manusia. Sofian Effendi. ed. Yogyakarta: Gadjah Mada University Press.

Rousseau, J.J. (2007). Du Contract Social (Perjanjian Sosial), Cetakan Pertama. Jakarta: Visimedia.

Simanjuntak, P,. J. (2005). Manajemen dan Evaluasi Kinerja. Jakarta: FE UI.

Sukamti, U. (1989). Manajemen Personalia/ Sumberdaya Manusia. Jakarta: P2IPTK, Dikti Depdikbud.

\section{Jurnal}

Higley, J., Burton, M.,G. (1989). The elite variable in demokratic transition and breakdown. American Sociological Review, 4 (no.1): 17-32

Rosemann, D., \& Shanahan, E., A. (2012). Defining and Archieving Normative Democratic Value in Parcipatory Budgeting Process. Public Administration Review. 72 (1) : 56-66 https://doi.org/10.1111/j.1540-6210.2011.02480.x 
Thalhah, HM. (2009). Teori Demokrasi dalam Wacana Ketatanegaraan Perspektif Pemikiran Hans Kelsen. Jurnal Hukum 16 (3), 413 - 422.

\section{Skripsi}

Muhibullah, M. (2016). Pengangkatan Perangkat Desa Perspektif Siyasah (Studi Pasa 6 Ayat 2 Perda Klaten No.10 Tabun 2006 Tentang Pengangkatan Dan Pemberbentian Perangkat Desa). Skripsi. Universitas Islam Negeri Sunan Kalijaga Yogyakarta.

Utami, N., A. (2015). Pengarub Rekruitmen Perangkat Desa Terhadap Kinerja Perangkat Pemerintah Desa di Kecamatan Randudongkal Kabupaten Pemalang. Skripsi. Fakultas Ilmu Sosial Dan Ilmu Politik. Universitas Pancasakti Tegal.

\section{Artikel Daring}

Florini, A. (2004). Bebind Closed Doors: Governmental Transparency Gives Way to Secrecy. Harvard International Review 26(1): 18-21. Diakses 18 Maret 2018 pada http://ink.library.smu.edu.sg/cgi/viewcontent.cgi?article=3580\&context =soss_research

\section{Undang-Undang dan Peraturan Pemerintah}

Undang-Undang Nomor 6 Tahun 2014 Tentang Desa

Peraturan Bupati Gresik Nomor 8 Tahun 2014 Tentang Pedoman Teknis Pengangkatan Perangkat Desa, 27 Januari 2014..

Peraturan Daerah Kabupaten Gresik Nomor 2 Tahun 2016 Tentang Pengangkatan dan Pemberhentian Perangkat Desa, 28 April 2016. 